\title{
Purification and characterization of a heat-stable alkaline protease from Bacillus stearothermophilus F1
}

\begin{abstract}
A thermophilic Bacillus stearothermophilus F1 that produced an extremely thermostable alkaline protease was isolated from decomposed oil palm branches. The isolated protease was purified to homogeneity by heat treatment, ultrafiltration and gel filtration chromatography with a 128 -fold increase in specific activity and $75 \%$ recovery. The protease, which is a serine-type enzyme, has a relative molecular mass of 33500 by sodium dodecyl sulphatepolyacrylamide gel electrophoresis but only 20000 by gel-filtration chromatography. The enzyme was optimally active at $\mathrm{pH} 9.0$ and was stable for $24 \mathrm{~h}$ at $70^{\circ} \mathrm{C}$ and in the $\mathrm{pH}$ range from 8.0 to 10.0. It was capable of hydrolysing many soluble and insoluble protein substrates but no esterase activity was detected. The enzyme activity was markedly inhibited by $\mathrm{Co} 2+$ and $\mathrm{Hg} 2+$, whereas $\mathrm{Mg} 2+, \mathrm{Fe} 2+, \mathrm{Cu} 2+, \mathrm{Zn} 2+$ and $\mathrm{Sr} 2+$ had little or no inhibitory effect. However, $\mathrm{Mn} 2+$ strongly activated the protease activity. The protease exhibited a high degree of thermostability $\left[\mathrm{t} 1 / 2\left(85^{\circ} \mathrm{C}\right)=4 \mathrm{~h},\left(90^{\circ} \mathrm{C}\right)=25 \mathrm{~min}\right.$ ]. The stability at higher temperatures $\left(85^{\circ} \mathrm{C}\right.$ and above) was shown to be dependent on the presence of $\mathrm{Ca} 2+$.
\end{abstract}

Keyword: Bacillus stearothermophilus F1; Thermostability; Protease; Enzyme purification 